Check for updates

Cite this: RSC Adv., 2017, 7, 56144

\title{
Stereoelectronic control of oxidation potentials of 3,7-bis(diarylamino)phenothiazines $\dagger$
}

Received 20th November 2017 Accepted 4th December 2017

DOI: 10.1039/c7ra12600j

rsc.li/rsc-advances

\author{
Ayumu Karimata, ${ }^{a}$ Shuichi Suzuki, (D)*ab Masatoshi Kozaki (D) a and Keiji Okada (D) *a
}

The influence of diarylamino $\left(\mathrm{Ar}_{2} \mathrm{~N}-\right)$ substituents on the oxidation potential of 3,7-bis(diarylamino) phenothiazines $\left(\mathrm{Ar}_{2} \mathrm{~N}\right)_{2}-\mathrm{PTZ}(1 \mathrm{a}-\mathrm{f}$, a: carbazolyl; b: dihydrodibenzoazepinyl; c: dibenzoazepinyl; $d$ : diphenylamino; e: phenothiazinyl; and $\mathrm{f}$ : phenoxazinyl) is investigated, where the $\mathrm{Ar}_{2} \mathrm{~N}$-substituent sequence $a \rightarrow f$ is aligned in the increasing order of their electron-donating ability. Interestingly, a different sequence of electron-donating ability for $\mathrm{Ar}_{2} \mathrm{~N}$-substituents was observed for the oxidation potentials of $\left(\mathrm{Ar}_{2} \mathrm{~N}\right)_{2}-\mathrm{PTZ}: 1 \mathrm{a}\left(E_{\mathrm{ox}}{ }^{1}=+0.35 \mathrm{~V}\right.$ vs. $\left.\mathrm{Fc} / \mathrm{Fc}^{+}\right)>1 \mathrm{f}(+0.30 \mathrm{~V})>1 \mathrm{e}(+0.15 \mathrm{~V})>1 \mathrm{~d}(-0.05 \mathrm{~V})>1 \mathrm{c}$ $(-0.19 \mathrm{~V})>1 \mathrm{~b}(-0.22 \mathrm{~V})$. The observed sequence can be explained by the stereoelectronic effect of the $\mathrm{Ar}_{2} \mathrm{~N}$-substituents to stabilize $\left(\mathrm{Ar}_{2} \mathrm{~N}\right)_{2}-\mathrm{PTZ}^{\cdot+}$. Clear-cut examples are observed in the crystal structure of $1 \mathrm{c}^{\cdot+}$ and $1 \mathrm{e}^{\cdot+}$, for which coplanar conformation is observed between the $\mathrm{PTZ}{ }^{\cdot+}$-plane and the planes of the $\mathrm{sp}^{2}$-hybridized nitrogen atoms in $\mathrm{Ar}_{2} \mathrm{~N}$-substituents through a large conformational change during the oxidation process of $\left(\mathrm{Ar}_{2} \mathrm{~N}\right)_{2}-\mathrm{PTZ}$.

\section{Introduction}

Phenothiazines (PTZs) are typical electron donors and have been used in charge transporting materials, ${ }^{1}$ molecular spin materials, ${ }^{2}$ dye-sensitized solar cells, ${ }^{3} \pi$-electron systems for photo-induced electron transfer, ${ }^{4}$ organic emitting devices, ${ }^{5}$ and charge transfer complexes. ${ }^{6}$ Tuning of the oxidation potential of these PTZs is important to widen their applicability. Several 3- or 3,7-substituted PTZs have been synthesized for various purposes. ${ }^{7}$ Müller reported the oxidation potentials and optical properties of various 3,7-diamino PTZs. ${ }^{8}$ Although PTZ derivatives with considerably low oxidation potentials have been synthesized, systematic substituent-effects based on their conformations confirmed by crystal structure analyses have not been reported.

In this paper, we investigated the diarylamino $\left(\mathrm{Ar}_{2} \mathrm{~N}-\right)$ substituent effect on the oxidation potentials of 3,7-bis(diarylamino)-10-methyl-10H'-phenothiazines $\left(\mathbf{A r}_{2} \mathbf{N}\right)_{2}-\mathbf{P T Z}(\mathbf{1 a - f}$, a: carbazolyl, b: dihydrodibenzoazepinyl, c: dibenzoazepinyl, d: diphenylamino, e: phenothiazinyl, and $\mathbf{f}$ : phenoxazinyl in Scheme 1), where the $\mathrm{Ar}_{2} \mathrm{~N}$-substituent sequence $\mathbf{a} \rightarrow \mathbf{f}$ is arranged in the ascending order of the electron-donating ability estimated from the oxidation potentials of the corresponding $\mathrm{N}$ -

${ }^{a}$ Graduate School of Science, Osaka City University, Sumiyoshi-ku, Osaka 558-8585, Japan. E-mail: okadak@sci.osaka-cu.ac.jp

${ }^{b}$ Graduate School of Engineering Science, Osaka University, Toyonaka, Osaka 5608531, Japan. E-mail: suzuki-s@chem.es.osaka-u.ac.jp

† Electronic supplementary information (ESI) available. CCDC 1572168, 1572169, 1572170, 1572171, 1572172, 1572173, 1572175, 1572186, 1572187, 1572188, 1572190 and 1572500. For ESI and crystallographic data in CIF or other electronic format see DOI: $10.1039 / \mathrm{c} 7 \mathrm{ra12600j}$ phenyldiarylamines $\mathbf{A r}_{2} \mathbf{N}-\mathbf{P h}$ (2a-f) (Scheme 1). Interestingly, a different sequence was observed for the oxidation potentials of 1a-f: 1a $>$ 1f $>1 \mathrm{e}>1 \mathrm{~d}>\mathbf{1 c}>\mathbf{1 b}$. The difference between 2a-f and $1 \mathrm{a}-\mathrm{f}$ is based on the oxidation moieties in the first oxidation potential; the oxidation potentials are primarily controlled by $\mathrm{Ar}_{2} \mathrm{~N}$-substituents in $\mathbf{A r}_{2} \mathbf{N}$-Ph, whereas the PTZ moieties are oxidized in $\left(\mathbf{A r}_{2} \mathbf{N}\right)_{2}-\mathbf{P T Z}$, except for $\mathbf{1 f}$ (vide infra). In the latter, a large stabilization is obtained through the conjugation between $\mathrm{Ar}_{2} \mathrm{~N}$ - and $\mathrm{PTZ}^{++}$moieties. For instance, in compound $\mathbf{1 d}^{++}$, the phenyl groups in the $\mathrm{Ar}_{2} \mathrm{~N}$-substituent can rotate around the $\mathrm{N}-\mathrm{C}\left(\mathrm{sp}^{2}\right)$ bonds to avoid steric repulsion between the $\mathrm{PTZ}^{+}$and the phenyl moieties, retaining the conjugation between the p-orbital on the nitrogen atom in the $\mathrm{Ar}_{2} \mathrm{~N}$ substituent and the singly occupied molecular orbital (SOMO) on the $\mathrm{PTZ}^{+}$moiety; such a conformation is not possible with the carbazolyl group in $\mathbf{1 a}^{\mathbf{}}$ because of the planar conformation. Furthermore, the $\mathrm{Ar}_{2} \mathrm{~N}$-substituents in $\mathbf{1 b}^{\mathbf{}}$ and $\mathbf{1 \mathbf { c } ^ { + + }}$ can uniquely adopt a coplanar conformation about the $\mathrm{PTZ}^{\cdot+}$ plane and the plane of $\mathrm{sp}^{2}$ nitrogen atom in $\mathrm{Ar}_{2} \mathrm{~N}$-substituents.

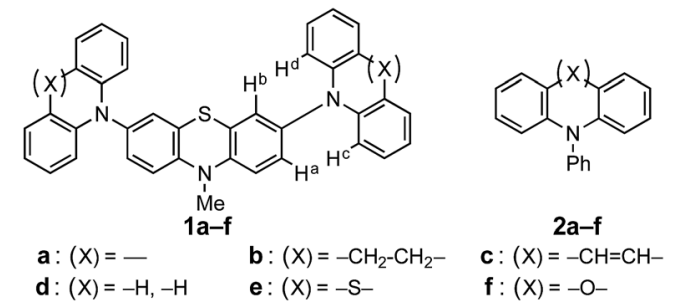

Scheme 1 Chemical structures of $\left(\operatorname{Ar}_{2} N\right)_{2}-P T Z(1 a-f)$ and $\operatorname{Ar}_{2} N-P h$ $(2 a-f)$. 
Previously, we have reported a unique structure of the PTZ trimer radical cation, the 10-phenyl derivative instead of the 10methyl derivative (1e); the PTZ trimer radical cation has a considerably deformed structure, which is stabilized by the conjugation between the inner $\mathrm{PTZ}^{+}$moiety and the $\mathrm{sp}^{2}$ hybridized nitrogen atoms in the outer PTZs. ${ }^{9}$ This paper presents a more general relationship between structures and oxidation potentials using various $\mathrm{Ar}_{2} \mathrm{~N}$-substituents; the proposed stereoelectronic stabilization is directly demonstrated by the crystal structure analyses of a series of $\left(\mathbf{A r}_{2} \mathbf{N}\right)_{2}-\mathbf{P T Z}^{\cdot+}$.

\section{Results and discussion}

\section{Syntheses of 3,7-bis(diarylamino)-10-methyl-10H' - phenothiazines and their radical cationic species}

Compounds $\left(\mathbf{A r}_{2} \mathbf{N}\right)_{2}-\mathbf{P T Z}$ were synthesized from 3,7-dibromoPTZ 3 (Scheme 2). Compound 3 was prepared according to the reported methods. ${ }^{10}$ Compound 3 was converted to the desired PTZ derivatives 1a-f by using Buchwald-Hartwig cross-coupling reactions with the corresponding diarylamines 4a-f. ${ }^{7}$ Single crystals of $\left(\mathbf{A r}_{2} \mathbf{N}\right)_{2}-\mathbf{P T Z}$ were obtained by recrystallization under suitable conditions (see Experimental section). However, we failed to obtain single crystals of $\mathbf{1 b}$. We could obtain the crystal structure of the model compound $\mathbf{1} \mathbf{b}^{\prime}$ (Scheme 3) using $N$-p-tolyl group instead of the $N$-methyl group in $\mathbf{1 b}$. The reference compounds $\mathbf{2 a - f}$ were also synthesized from the corresponding diarylamines and bromobenzene using Buchwald-Hartwig reactions.

We prepared the radical cationic species of $\left(\mathbf{A r}_{2} \mathbf{N}\right)_{2}-\mathbf{P T Z}$ by chemical oxidation using suitable reagents (Scheme 2) to study their detailed molecular structures by X-ray crystal structure analysis. The compounds $\mathbf{1 a}, \mathbf{1 b}, \mathbf{1 d}$, and 1e were oxidized using tris(4-bromophenyl)aminium hexafluoroantimonate $\left(\right.$ TBPA $\left.^{++} \cdot \mathbf{S b F}_{6}{ }^{-}\right)$to the corresponding radical cationic salts $\left(\mathbf{1 a}^{\cdot+} \cdot \mathbf{S b F}_{\mathbf{6}}{ }^{-}, \mathbf{1 b}^{\cdot+} \cdot \mathbf{S b F}_{\mathbf{6}}{ }^{-}, \mathbf{1 d}^{\cdot+} \cdot \mathbf{S b F}_{\mathbf{6}}{ }^{-}, \mathbf{1 e}^{\cdot+} \cdot \mathbf{S b F}_{\mathbf{6}}{ }^{-}\right)$. The single crystals of these radical cationic salts could be obtained by recrystallization from suitable solvents. ${ }^{11}$ Although we synthesized $1 \mathbf{c}^{\cdot+} \cdot \mathbf{S b F}_{\mathbf{6}}{ }^{-}$and $\mathbf{1 f}^{\mathbf{0}^{+}} \cdot \mathbf{S b F}_{\mathbf{6}}{ }^{-}$, we could not obtain their single crystals for crystal structure analysis. Alternatively, we could obtain single crystals of $\mathbf{1 c}^{\cdot+} \cdot \mathbf{G a B r}_{\mathbf{4}}{ }^{-}$and $\mathbf{1 f}^{{ }^{++}} \cdot \mathbf{G a B r}_{\mathbf{4}}{ }^{-}$, which could be prepared from $1 \mathrm{c}$ and $\mathbf{1 f}$ by treatments with

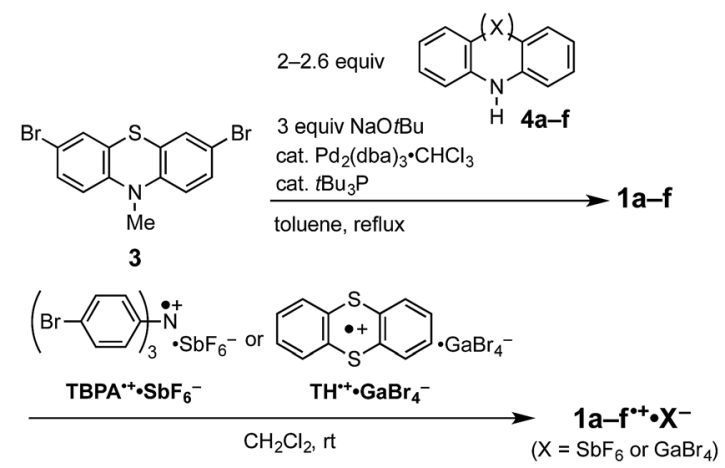

Scheme 2 Synthetic methods of $\left(\mathrm{Ar}_{2} \mathrm{~N}\right)_{2}-\mathrm{PTZ}(1 \mathrm{a}-\mathrm{f})$ and $\left(\mathrm{Ar}_{2} \mathrm{~N}\right)_{2}-$ $\mathrm{PTZ}^{\cdot+} \cdot \mathrm{X}^{-}\left(1 \mathrm{a}-\mathrm{f}^{\cdot+} \cdot \mathrm{X}^{-}\right)$.



Scheme 3 Chemical structure of $1 b^{\prime}$

thianthrenium tetrabromogallate $\left(\mathbf{T H}^{++} \cdot \mathbf{G a B r}_{\mathbf{4}}{ }^{-}\right) \cdot{ }^{\mathbf{1 1}, \mathbf{1 2}}$ These radical cationic species are quite stable for days, even under aerated conditions in both solution state and solid state.

Oxidation potentials of 3,7-bis(diarylamino)-10-methyl-10 $H^{\prime}$ phenothiazines

The cyclic voltammograms are shown in Fig. 1 for 1a-e and Fig. $\mathrm{S} 1 \dagger$ for 1f, and their oxidation potentials are listed in Table 1. In order to gain insight into the electron donating ability of the $\mathrm{Ar}_{2} \mathrm{~N}$-substitutents, oxidation potentials of $\mathbf{A r}_{2} \mathbf{N}-\mathbf{P h}(\mathbf{2 a}-\mathbf{f})$ and $\mathrm{N}$-methyl-10H-phenothiazine (5) were also measured (Table 1), which reflects the electron donating ability of the $\mathrm{Ar}_{2} \mathrm{~N}$ substituent: $E_{\mathrm{ox}}{ }^{1}(\mathbf{2 a}-\mathbf{f})$ is aligned in the sequence of $\mathbf{a} \approx \mathbf{b}>\mathbf{c}$ $>\mathbf{d} \gg \mathbf{e}>\mathbf{f}$ (Table 1$)$.

The oxidation potentials of $\left(\mathbf{A r}_{2} \mathbf{N}\right)_{2}-\mathbf{P T Z}$ were considerably lower than those of $\mathbf{A r}_{2} \mathbf{N}$-Ph, except for $\mathbf{1 f}$ (Table 1). Compound 1a has a lower oxidation potential $\left(+0.35 \mathrm{~V} v s\right.$. Fc/Fc $\left.{ }^{+}\right)$than that $(+1.08 \mathrm{~V})$ of $2 \mathrm{a}$, because the oxidation in 1a occurs in the central

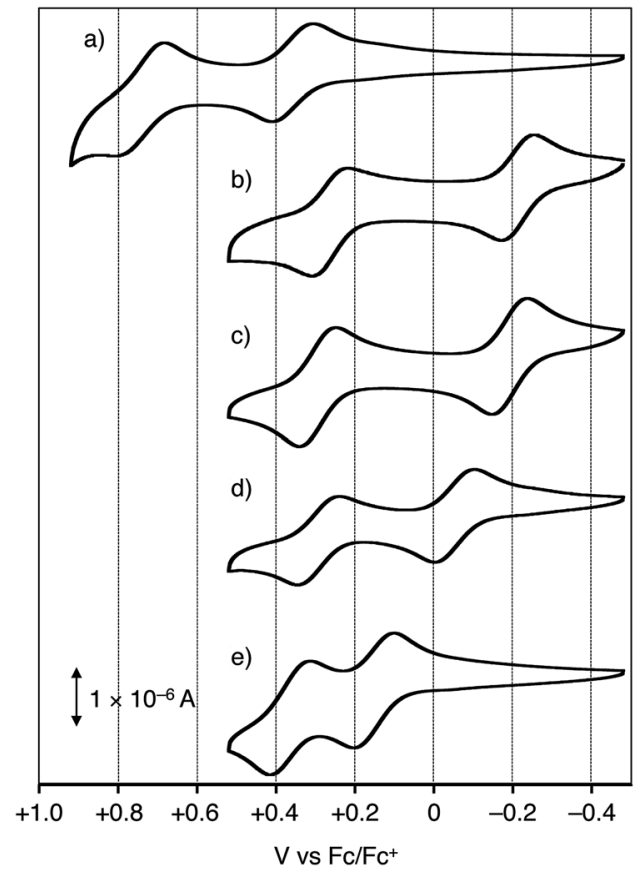

Fig. 1 Cyclic voltammograms of (a) 1a, (b) 1b, (c) 1c, (d) $1 d$, and (e) 1 e in dichloromethane: conditions of cyclic voltammetry: $n \mathrm{Bu}_{4} \mathrm{~N}^{+} \cdot \mathrm{ClO}_{4}{ }^{-}$as an electrolyte; glassy carbon and $\mathrm{Pt}$ wire as a working and counter electrode; in $\mathrm{CH}_{2} \mathrm{Cl}_{2} ; \mathrm{Fc} / \mathrm{Fc}^{+}=+0.49 \mathrm{~V}$ vs. SCE. 
Table 1 Oxidation potentials of 5, $\left(\mathrm{Ar}_{2} \mathrm{~N}\right)_{2}-\mathrm{PTZ}(1 \mathrm{a}-\mathrm{f})$, and $\mathrm{Ar}_{2} \mathrm{~N}-\mathrm{Ph}$ $(2 a-f)^{a}$

\begin{tabular}{lll}
\hline Compound & $E_{\text {Ox }}{ }^{1}\left[\mathrm{~V} v s . \mathrm{Fc} / \mathrm{Fc}^{+}\right]$ & $E_{\text {Ox }}{ }^{2}\left[\mathrm{~V} v s . \mathrm{Fc} / \mathrm{Fc}^{+}\right]$ \\
\hline $\mathbf{5}$ & $+0.31^{b}$ & - \\
$\mathbf{1 a}$ & $+0.35^{b}$ & $+0.75^{b}$ \\
$\mathbf{1 b}$ & $-0.22^{b}$ & $+0.27^{b}$ \\
1c & $-0.19^{b}$ & $+0.30^{b}$ \\
1d & $-0.05^{b}$ & $+0.29^{b}$ \\
1e & $+0.15^{b}$ & $+0.36^{b}$ \\
1f & $+0.30^{c}$ & - \\
2a & $+1.08^{d}$ & - \\
2b & $+1.08^{d}$ & - \\
2c & $+0.94^{d}$ & - \\
2d & $+0.80^{d}$ & - \\
2e & $+0.26^{b}$ & - \\
2f & $+0.24^{b}$ & -
\end{tabular}

${ }^{a}$ Conditions of cyclic voltammetry: $n \mathrm{Bu}_{4} \mathrm{~N}^{+} \cdot \mathrm{ClO}_{4}{ }^{-}$as an electrolyte; glassy carbon and $\mathrm{Pt}$ wire as a working and counter electrode, respectively; in dichloromethane; $\mathrm{Fc} / \mathrm{Fc}^{+}=+0.49 \mathrm{~V}$ vs. SCE. ${ }^{b}$ Half wave potential of a reversible oxidation wave. ${ }^{c}$ Two-electron oxidation processes of phenoxazine moieties. ${ }^{d}$ Peak potential, respectively. $E_{\mathrm{ox}}{ }^{1}$, $E_{\mathrm{ox}}{ }^{2}$ : first and second oxidation potentials.

PTZ moiety rather than the outer carbazolyl-moieties ( $c f . E_{\mathrm{ox}}{ }^{1}$ for 5 and $\mathbf{2 a}$ ). The oxidation potentials of $\mathbf{1 b}$ and $\mathbf{1 c}$ with sevenmembered ring systems $\left(E_{\mathrm{ox}}{ }^{1} \approx-0.2 \mathrm{~V}\right)$ are considerably lower than those of $2 \mathbf{b}$ and $2 \mathbf{c}\left(E_{\mathrm{ox}}{ }^{1} \approx+1.0 \mathrm{~V}\right)$ and even lower than that of $5(+0.31 \mathrm{~V})$. The observed sequence of the oxidation potentials in 1a-f $\left(E_{\text {ox }}^{1}(1 \mathrm{a})>E_{\text {ox }}^{1}(1 \mathbf{f})>E_{\text {ox }}^{1}(1 \mathrm{e})>E_{\text {ox }}^{1}(1 \mathrm{~d})>E_{\text {ox }}^{1}(1 \mathrm{c})>\right.$ $\left.E_{\text {ox }}{ }^{1}(\mathbf{1 b})\right)$ is totally different from those of the $\mathrm{Ar}_{2} \mathrm{~N}$-substituents. ${ }^{13}$

$\mathrm{X}$-ray diffraction studies revealed that the compounds with low oxidation potential (1b, 1c, and 1d) can adopt a coplanar conformation about the $\mathrm{PTZ}^{\cdot+}$ plane and the plane of $\mathrm{sp}^{2}$ hybridized nitrogen atom in the radical cation states by a structural change from the neutral states (vide infra), as observed in the PTZ trimer radical cation. ${ }^{9}$ However, $\mathbf{1 a}^{{ }^{+}}$and $\mathbf{1 f}^{*+}$ cannot undergo such conformational changes due to their rigid planar structures of $\mathrm{Ar}_{2} \mathrm{~N}$-substituents, ${ }^{\mathbf{1 4}}$ which causes steric repulsion between $\mathrm{H}^{\mathrm{a}}\left(\mathrm{H}^{\mathrm{b}}\right)$ and $\mathrm{H}^{\mathrm{c}}\left(\mathrm{H}^{\mathrm{d}}\right)$ in the structure of $\left(\mathbf{A r}_{2} \mathbf{N}\right)_{2}-\mathbf{P T Z}$, as shown in Scheme 1.

It is to be noted that the oxidation wave for $\mathbf{1 f}(+0.3 \mathrm{~V})$ is assigned to sequential two-electron oxidations of outer phenoxazines (Table 1, Fig. S1†). This assignment is compatible with the following three observations; (1) slightly lower oxidation potential of $2 \mathbf{f}(+0.24 \mathrm{~V})$ than those of $2 \mathrm{e}(+0.26 \mathrm{~V})$ and 5


PTZ with a butterfly structure (vide infra, Fig. $3(\mathrm{l})$ and S2 $\dagger$ ), and (3) UV-vis-NIR spectrum of $\mathbf{1 f}^{\mathbf{}^{+}} \cdot \mathbf{G a B r}_{\mathbf{4}}{ }^{-}$showing a strong absorption at $\sim 500 \mathrm{~nm}$ assigned to the terminal phenoxazine radical cation (Fig. $\mathrm{S} 3 \dagger$ ). These results indicate that the oxidation potential of the central PTZ moiety in 1f should be more positive than $+0.30 \mathrm{~V}$.

\section{$\mathrm{X}$-ray crystal structure analysis and substituent effect in the oxidation of $\left(\mathrm{Ar}_{2} \mathrm{~N}\right)_{2}-\mathrm{PTZ}$}

To demonstrate the conformation-dependent substituent effect, we analyzed the X-ray crystal structure of both neutral and radical cationic species (Fig. 2 and 3). ${ }^{11}$ The molecular structures of neutral species $\mathbf{1 a}, \mathbf{1} \mathbf{b}^{\prime}$ (as a model compound of 1b), 1c-f, and radical cationic species $\mathbf{1 a - \mathbf { f } ^ { + + }}$ are shown in Fig. 3.

The central PTZ moiety of $\left(\mathbf{A r}_{2} \mathbf{N}\right)_{2}-\mathbf{P T Z}$ takes a butterfly structure (dihedral angles between planes A/B: $35-50^{\circ}$ ) (Table 2, Fig. 2 and 3), ${ }^{4 a, 9}$ whereas that of $\left(\mathbf{A r}_{2} \mathbf{N}\right)_{2}-\mathbf{P T Z}{ }^{++}$except for $\mathbf{1 f}^{\cdot+}$ has an almost planar structure $\left(\mathbf{A} / \mathbf{B}<17.7^{\circ}\right)$, indicating that the central PTZ moiety of $\mathbf{1 a}-\mathbf{e}^{\cdot+}$ is in the radical cationic state. The


other radical cations $1 \mathbf{a}-\mathbf{e}^{\cdot+}$. The central PTZ moiety of $\mathbf{1 f}^{\mathbf{}^{+}}$has a butterfly structure (A/B: $\left.45.4^{\circ}\right)$ similar to that of $\mathbf{1 f}\left(\mathbf{A} / \mathbf{B}: 45.4^{\circ}\right)$, showing that the central PTZ moiety of $\mathbf{1 f}^{++}$is in the neutral state. It is also interesting that one of the two outer phenoxazine moieties has a planer structure with shorter $\mathrm{C}-\mathrm{O}$ bond lengths (Fig. $\mathrm{S} 2 \dagger$ ). These results indicate that the planar phenoxazine moiety is in the radical cationic state, whereas the other phenoxazine moiety is in the neutral state.

Table 2 lists the bond lengths R(N1-C6(7)) and R(S-C1(12)) of the central PTZ moiety in the neutral and the radical cationic states. These $\mathrm{N}-\mathrm{C}\left(\mathrm{sp}^{2}\right)$ and $\mathrm{S}-\mathrm{C}\left(\mathrm{sp}^{2}\right)$ bond lengths in the radical cationic state are slightly shorter than those in the neutral state by reflection of the antibonding character of these bonds in SOMOs of $1 \mathrm{a}-\mathrm{e}^{\cdot+}$ (Fig. S4†).

In these radical cations, the small dihedral angle between planes $\mathbf{A}$ and $\mathbf{C}(\mathbf{A} / \mathbf{C})$ (or $\mathbf{B}$ and $\mathbf{D}(\mathbf{B} / \mathbf{D})$ ) permits the ease of conjugation between the PTZ $\pi$-orbitals and the adjacent nitrogen p-orbital in the $\mathrm{Ar}_{2} \mathrm{~N}$-substituents. Interestingly, compounds $\mathbf{1} \mathbf{c}^{\cdot+}$ and $1 \mathbf{e}^{{ }^{+}}$experienced large conformational changes to diminish $\mathbf{A} / \mathbf{C}$ and $\mathbf{B} / \mathbf{D}$. The compounds having low oxidation potentials, i.e. $\mathbf{1 b}, \mathbf{1 c}$, and $\mathbf{1 d}$, have small average dihedral angle in their radical cationic state: $4.8^{\circ}\left(\mathbf{1 b}^{\circ+}\right), 6.4^{\circ}$ $\left(\mathbf{1 c}^{\cdot+}\right)$, and $7.8^{\circ}\left(\mathbf{1 d}^{\cdot+}\right)$. Compound $1 \mathrm{a}$ had the largest dihedralangle in the radical cation state except for $\mathbf{1 f}^{\cdot+}$ and exhibited the most positive oxidation potential. Furthermore, effective conjugations about $\mathrm{sp}^{2}$ nitrogen atom and the central $\mathrm{PTZ}^{++}$for the low-oxidation-potential compounds (1b, 1c, and 1d) are reflected by shorter bond lengths R(N2(3)-C3(10)) (1.37-1.38 Å) in the radical cation structures. These results clearly indicate the importance of radical cation structures for the oxidation potentials.

It is interesting to consider the mechanism of oxidation of the adsorbed neutral state $\left(\mathbf{A r}_{2} \mathbf{N}\right)_{2}-\mathbf{P T Z}$ for cyclic voltammogram measurements; oxidation is accompanied by the large conformational change to stabilize the $\left(\mathbf{A r}_{2} \mathbf{N}\right)_{2}-\mathbf{P T Z}{ }^{\cdot+}$. The oxidation of neutral $\left(\mathbf{A r}_{2} \mathbf{N}\right)_{2}-\mathbf{P T Z}$ on the electrode surface starts

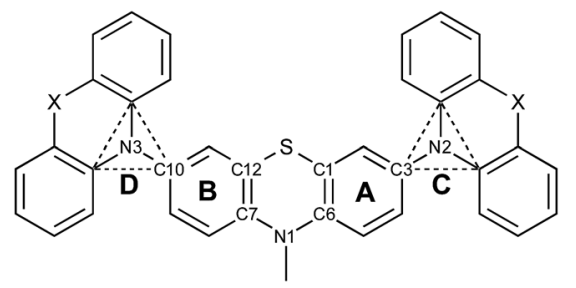

Fig. 2 Specific names of atoms and planes for discussion of crystal structures. 
a)

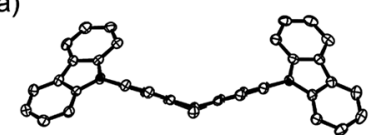

c)

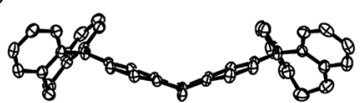

e)

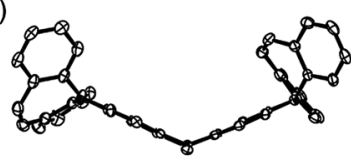

g)

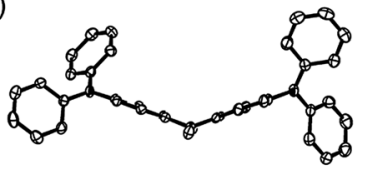

i)

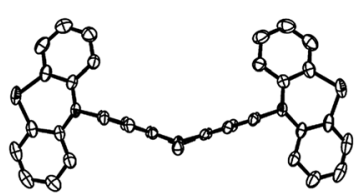

k)



b)

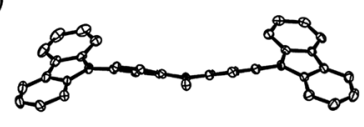

d)

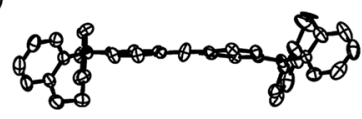

f)

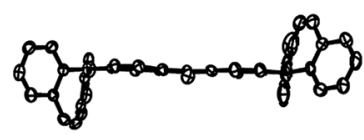

h)

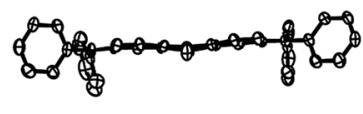

j)

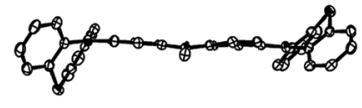

l)

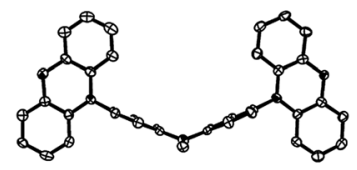

Fig. 3 ORTEP views along the $\mathrm{N}-\mathrm{S}$ axis (50\% probabilities); (a) 1a, (b) $1 a^{\cdot+} \cdot \mathrm{SbF}_{6}{ }^{-}$, (c) $1 b^{\prime}$ (the $p$-tolyl group was omitted for clarity), (d) $1 b^{*+} \cdot \mathrm{SbF}_{6}{ }^{-}$, (e) $1 \mathrm{c}$, (f) $1 \mathrm{c}^{\cdot+} \cdot \mathrm{GaBr}_{4}^{-}$, (g) $1 \mathrm{~d}$, (h) $1 \mathrm{~d}^{++} \cdot \mathrm{SbF}_{6}{ }^{-}$, (i) $1 \mathrm{e}$, (j)

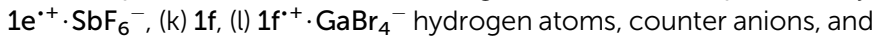
crystal solvents were omitted for clarity.

from the oxidation of the adsorbed molecular edge of the $\mathrm{Ar}_{2} \mathrm{~N}$ moiety rather than the central PTZ moiety covered by the bulky groups to produce $\mathbf{A r}_{2} \mathbf{N}^{++}-\mathbf{P T Z}$; it then quickly changes to more stable hole-shifted $\mathbf{A r}_{2} \mathbf{N}-\mathbf{P T Z}^{++}$with large conformational change. These processes occur very rapidly, so that the cyclic voltammograms exhibit usual reversible waves (Fig. 1). In order to obtain insight into such hole-shift processes, we previously investigated photo-induced electron transfer of a (PTZ trimer)anthraquinone (PTZ3-PTZ2-PTZ1-B-AQ, B: bridge) dyad ${ }^{4 a}$ in which electron transfer via through-bond interaction from PTZ

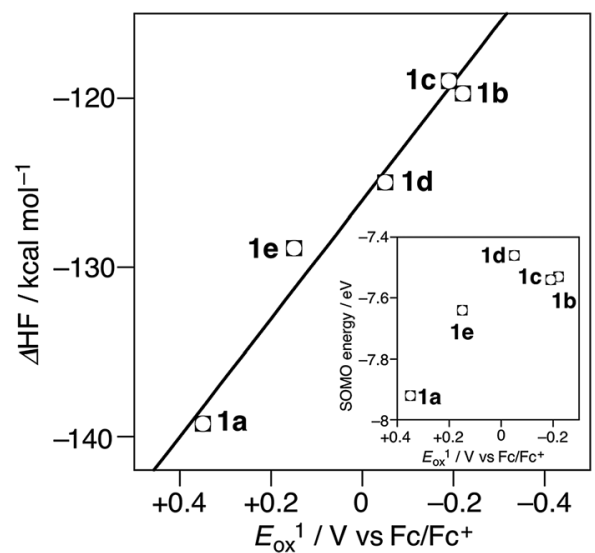

Fig. 4 The plots of $E_{o x}{ }^{1}$ of $1 a-e$ vs. calculated heat of formation difference $(\Delta \mathrm{HF})$ between $1 \mathrm{a}-\mathrm{e}$ and $1 \mathrm{a}-\mathrm{e}^{\cdot+}$. (inset) The plots of $E_{\mathrm{ox}}{ }^{1} \mathrm{vs}$. SOMO energy of $1 \mathrm{a}-\mathrm{e}^{\cdot+}$.

trimer to the excited anthraquinone (AQ) to give PTZ3-PTZ2-

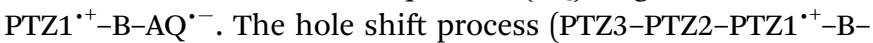
$\mathrm{AQ}^{--} \rightarrow \mathrm{PTZ}^{-\mathrm{PTZ}_{2}}{ }^{+}-\mathrm{PTZ1}^{\left.-\mathrm{B}-\mathrm{AQ}^{--}\right)}$with large conformational change was directly monitored by the transient absorption spectroscopy using a time constant of $6 \mathrm{~ns}$. Thus, the oxidation of $\left(\mathbf{A r}_{2} \mathbf{N}\right)_{2}-\mathbf{P T Z}$ is associated with both neutral and radical cation geometries.

We also carried out theoretical calculation on the stereoelectronic effects by theoretical calculation using Gaussian 09 on the basis of (U)B3LYP/6-31G** level of theory in order to obtain a general relationship between structures and oxidation potentials. ${ }^{15,16}$ The calculated HOMO energy levels of $1 \mathrm{a}-\mathbf{e}$ are not correlated to the oxidation potentials (HOMO energy of 1a $(-5.18 \mathrm{eV})>1 \mathrm{e}(-5.00 \mathrm{eV})>1 \mathrm{~d}(-4.58 \mathrm{eV})>1 \mathrm{~b}(-4.24 \mathrm{eV})>1 \mathrm{c}$ $(-4.19 \mathrm{eV}))$ (Fig. S6 $\dagger$ ). The calculated SOMO energy levels of 1a$\mathrm{e}^{\cdot+}$ are in the order of $1 \mathrm{a}^{\cdot+}(-7.92 \mathrm{eV})>1 \mathrm{e}^{\cdot+}(-7.64 \mathrm{eV})>1 \mathbf{c}^{\cdot+}$ $(-7.54 \mathrm{eV})>\mathbf{1 b}(-7.53 \mathrm{eV})>\mathbf{1 d}^{\cdot+}(-7.46 \mathrm{eV})($ Fig. S4†) are also not correlated to oxidation potentials; the sequence agrees with the experimentally observed oxidation potentials except for the position of 1d (Fig. 4, inset). This consideration also indicates the importance of radical cationic geometry in the oxidation potentials of 1a-e. Finally, the stabilization-energy gain from the neutral to the radical cation state, i.e. the calculated heat of formation differences between optimized structures in neutral

Table 2 Selected bond lengths (averaged) and dihedral angles for $\left(\operatorname{Ar}_{2} N\right)_{2}-\mathrm{PTZ}(1 \mathrm{a}-\mathrm{f})$ and $\left(\operatorname{Ar}_{2} \mathrm{~N}\right)_{2}-\mathrm{PTZ}^{\cdot+}\left(1 \mathrm{a}-\mathrm{f}^{\cdot+}\right)^{a}$

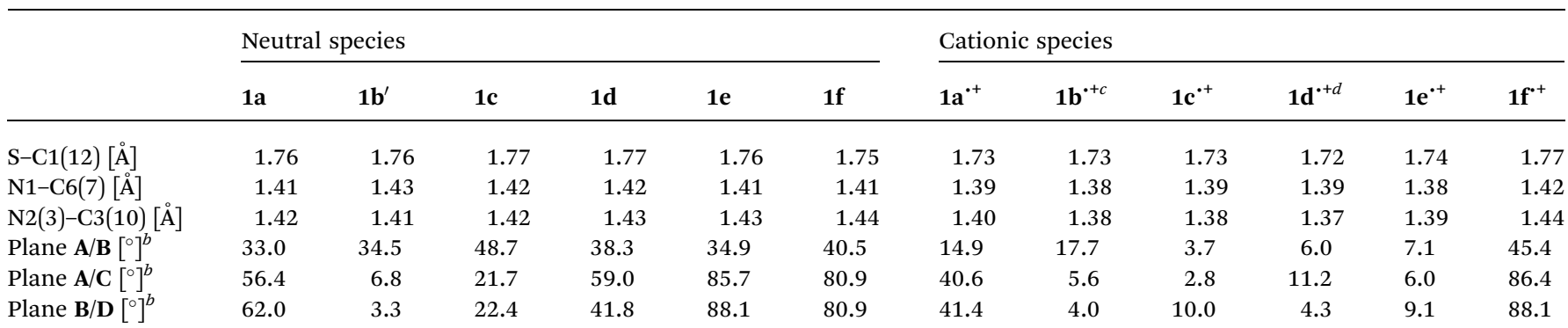

${ }^{a}$ See Fig. 2 for naming of atoms and planes in $\left(\mathbf{A r}_{2} \mathbf{N}\right)_{2}-$ PTZ. ${ }^{b}$ Dihedral angles between two planes. ${ }^{c}$ Averaged values of two crystallographically independent species. ${ }^{d}$ Averaged values of four crystallographically independent species. 
a)

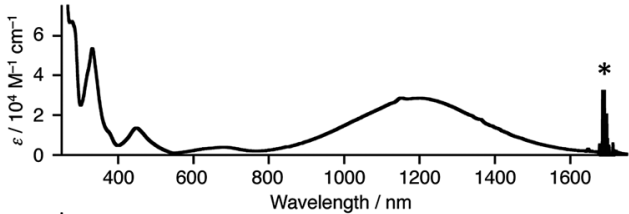

b)

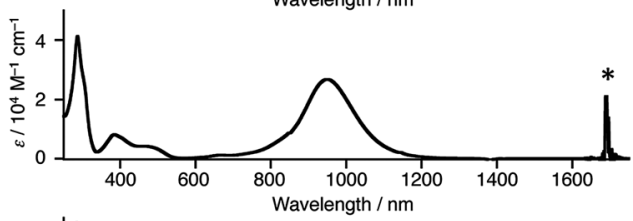

c)

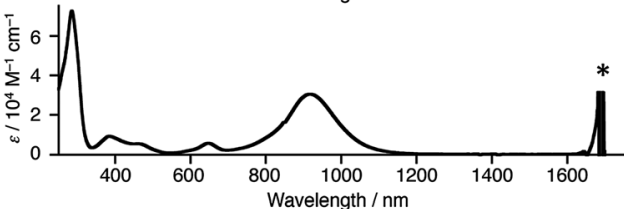

d)

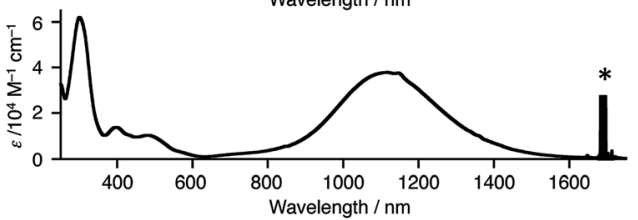

e)

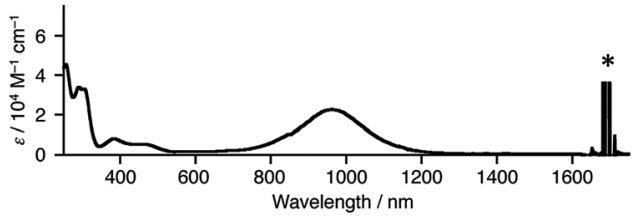

Fig. 5 UV-vis NIR spectra of (a) $1 a^{\cdot+} \cdot \mathrm{SbF}_{6}{ }^{-}$, (b) $1 b^{\cdot+} \cdot \mathrm{SbF}_{6}{ }^{-}$, (c) $1 c^{\cdot+} \cdot \mathrm{GaBr}_{4}{ }^{-}$, (d) $1 \mathrm{~d}^{\cdot+} \cdot \mathrm{SbF}_{6}{ }^{-}$, and (e) $1 \mathrm{e}^{\cdot+} \cdot \mathrm{SbF}_{6}{ }^{-}$in dichloromethane. Asterisks were denoted peaks of solvent.

and radical cation states $(\Delta \mathrm{HF})$ are considered: the plots of $\Delta \mathrm{HF}$ $\left(-139.23 \mathrm{kcal} \mathrm{mol}^{-1}(\mathbf{1 a}),-119.70(\mathbf{1 b}),-118.97\right.$ (1c) $),-124.98$ $(\mathbf{1 d}),-128.85(\mathbf{1 e}))$ vs. $E_{\mathrm{ox}}{ }^{1}$ provides a good correlation (correlation coefficient: $R^{2}=0.983$; Fig. 4).

As apparent from the crystal structures of $1 \mathbf{a}^{-e^{++}}$, the central $\mathrm{PTZ}^{+}$can be stabilized by the conjugation with the nitrogen p-orbitals in $\mathrm{Ar}_{2} \mathrm{~N}$-substituents. These $\pi$-conjugation gives rise to broad and intense intramolecular charge transfer (CT) bands in near infrared region: $\mathbf{1 a}^{\cdot+}\left(\lambda_{\max }=1200 \mathrm{~nm}\right.$ in dichloromethane), $\mathbf{1 b}^{++}(950 \mathrm{~nm}), \mathbf{1 c}^{\mathbf{}^{++}}(918 \mathrm{~nm}), \mathbf{1 d}^{++}(1118$ $\mathrm{nm}$ ), and $1 \mathbf{e}^{\cdot+}$ (963 $\left.\mathrm{nm}\right)$ (Fig. 5). These differences are almost consistent with the results of theoretical calculations by TDDFT method (see, ESI $\dagger$ ).

\section{Conclusions}

We designed and prepared a series of 3,7-bis(diarylamino) phenothiazines $\left(\mathbf{A r}_{2} \mathbf{N}\right)_{2}-\mathbf{P T Z}(\mathbf{1 a}-\mathbf{f})$ and investigated relationship between their oxidation potentials and their molecular structures. X-ray crystal structural analyses and theoretical calculations indicated a unique stereoelectronic effect on PTZs, which strongly depends on the conformation of $\mathrm{Ar}_{2} \mathrm{~N}$ substituent.

The oxidations of $1 \mathrm{c}$ and $1 \mathrm{e}$ are accompanied by the large conformational changes. In compound 1a, the freedom of $\mathrm{Ar}_{2} \mathrm{~N}-$ substituent is restricted only by rotation of the carbazolyl group.
Although the manner of stabilization of $\left(\mathbf{A r}_{2} \mathbf{N}\right)_{2}-\mathbf{P T Z}^{++}\left(\mathbf{1} \mathbf{a}-\mathrm{e}^{\cdot+}\right)$ is highly substituent-dependent, these substituent-dependent oxidation potentials were shown to be proportional to the energy gain from the neutral state to the radical cation state.

The radical cationic species $\left(\mathbf{A r}_{2} \mathbf{N}\right)_{2}-\mathbf{P T Z}^{\cdot+}$ were quite stable under aerobic conditions in both solution and the solid states. In addition, the radical cationic species $1 \mathbf{a}^{-} \mathbf{e}^{\cdot+}$ showed intense intermolecular CT bands in near infrared region.

Although this study was particularly investigated for the PTZ derivatives, the observed stereoelectronic substituent-effect must be uniformly applicable to electron rich aromatic or benzo-condensed $\pi$-conjugated systems.

\section{Experimental}

\section{General information}

${ }^{1} \mathrm{H}$ and ${ }^{13} \mathrm{C}$ NMR spectra were recorded on a Bruker NanoBay 300 spectrometer. MALDI-TOF-MS was measured on a Shimadzu-Kratos AXIMA-CFR Plus spectrometer using dithranol as a matrix reagent. Absorption spectra were measured with a JASCO V-750 UV-vis spectrometer and Hitachi U-3500L spectrometer. X-ray data were collected by a Rigaku Saturn CCD system with graphite monochromated Mo-K $\alpha$ radiation. Melting points were measured with a hot-stage apparatus and the values are uncorrected. Redox potentials were measured using ALS electrochemical analyzer MODEL 610A in a conventional three-electrode cell equipped with a glassy carbon as a working electrode and a platinum wire as a counter electrode with a SCE reference electrode. The measurements were carried out with a sweep rate of $100 \mathrm{mV} \mathrm{s}^{-1}$ in suitable solvent containing $0.1 \mathrm{M}$ tetra- $n$-butylammonium perchlorate $\left(n \mathrm{Bu}_{4}\right.$ $\mathrm{N}^{+} \cdot \mathrm{ClO}_{4}^{-}$) as an electrolyte. The redox potentials were finally corrected by the ferrocene/ferrocenium couple $\left(\mathrm{Fc} / \mathrm{Fc}^{+}\right)$.

Silica gel 60 (100-200 mesh) was used for column chromatography. All commercially available compounds were reagent grade and used without further purification. Dichloromethane $\left(\mathrm{CH}_{2} \mathrm{Cl}_{2}\right)$, and acetonitrile $\left(\mathrm{CH}_{3} \mathrm{CN}\right)$ were dried and distilled over calcium hydride. Toluene, benzene, tetrahydrofuran (THF), and diethyl ether $\left(\mathrm{Et}_{2} \mathrm{O}\right)$ were dried and distilled over sodium. Ethanol (EtOH) and methanol (MeOH) were dried and distilled over magnesium.

Tris(4-bromophenyl)aminium hexafluoroantimonate $\left(\mathbf{T B P A}^{\cdot+} \cdot \mathbf{S b F}_{\mathbf{6}}{ }^{-}\right)$was prepared from tris(4-bromophenyl)amine and silver hexafluoroantimonate according to the literature with some modification. ${ }^{17}$ 3,7-Dibromo-10-methyl-10H-phenothiazine (3) was prepared according to the literature. ${ }^{10} 5,5^{\prime}-(10-$ Tolyl-10H-phenothiazine-3,7-diyl)bis(10,11-dihydro-5H-dibenzo

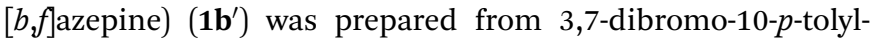
$10 H$-phenothiazine and 10,11-dihydro-5H-dibenzo[ $b$ f $]$ ]azepine (4b) according to the synthetic method of $\mathbf{1 b}$. Single crystals of $\mathbf{1 b}$ ' suitable for X-ray crystal structure analysis were obtained by recrystallization from toluene-EtOH.

\section{Synthetic procedures}

Thianthrenium tetrabromogallate $\left(\mathrm{TH}^{++} \cdot \mathbf{G a B r}_{4}{ }^{-}\right)$. Oxidant $\mathbf{T H}^{\cdot+} \cdot \mathbf{G a B r}_{4}{ }^{-}$was prepared according to the same procedure of 
thianthrenium radical cations reported by our research group. ${ }^{\mathbf{1 2}}$ The oxidation of thianthrene was carried out in an electrochemical cell, which has two compartments (each $25 \mathrm{~mL}$ ) separated by glass filter and equipped with platinum electrodes $\left(15 \times 15 \mathrm{~mm}^{2}\right)$. An electrolyte solution of tetra- $n$-butylammonium tetrabromogallate $\left(n \mathrm{Bu}_{4} \mathrm{~N}^{+} \cdot \mathrm{GaBr}_{4}{ }^{-}\right)(1.35 \mathrm{~g}, 2.13 \mathrm{mmol})$ in $\mathrm{CH}_{2} \mathrm{Cl}_{2}(50 \mathrm{~mL})$ was prepared. Half of the solution was placed to the cathodic compartment in the cell. Thianthrene $(381 \mathrm{mg}$, $1.76 \mathrm{mmol}$ ) was dissolved in the remaining electrolyte solution, and this solution was placed to the anodic compartment. Both compartments in the cell were purged argon for a few minutes. The electrolysis was carried out at a constant current $(1.0 \mathrm{~mA})$ using a galvanostat. After 1 day, purple crystals were deposited on the surface of the platinum electrode at the anodic compartment. These generating crystals were repeatedly collected several times (682 mg, 64\% after third cycle). $\mathbf{T H}^{\cdot+} \cdot \mathbf{G a B r}_{4}{ }^{-}: \mathrm{C}_{12} \mathrm{H}_{8} \mathrm{~S}_{2} \cdot \mathrm{GaBr}_{4}$; MW 605.66; deep purple powder; mp $212{ }^{\circ} \mathrm{C}$ (decomp.); ESR (powder) $g=2.0075$ as three line signals with anisotropy of $g$-factor $\left(g_{X X}=2.0131, g_{Y Y}=2.0077\right.$, $\left.g_{Z Z}=2.0016\right)$; anal. calcd for $\mathrm{C}_{13} \mathrm{H}_{8} \mathrm{~S}_{2} \cdot \mathrm{GaBr}_{4}: \mathrm{C}, 23.80 ; \mathrm{H}, 1.33$. Found. C, 23.87; H, 1.30 .

3,7-Di(9H-carbazol-9-yl)-10-methyl-10H-phenothiazine (1a). A mixture of dibromophenothiazine 3 (186 $\mathrm{mg}, 0.500 \mathrm{mmol})$, carbazole (4a) (209 mg, $1.25 \mathrm{mmol}$ ), tris(dibenzylideneacetone) dipalladium-chloroform $\left(\mathrm{Pd}_{2}(\mathrm{dba})_{3} \cdot \mathrm{CHCl}_{3}\right)(11.4 \mathrm{mg}, 0.001$ $\mathrm{mmol})$, a toluene solution of tri-tert-butylphosphine $\left(t \mathrm{Bu}_{3} \mathrm{P}\right)$ (20 mM, $1.0 \mathrm{~mL}, 0.002 \mathrm{mmol})$, sodium tert-butoxide ( $\mathrm{NaOt} \mathrm{Bu})$ $(144 \mathrm{mg}, 1.50 \mathrm{mmol})$, and toluene $(4 \mathrm{~mL})$ was stirred at $110{ }^{\circ} \mathrm{C}$ under a nitrogen atmosphere for $20 \mathrm{~h}$. After cooling to room temperature, the insoluble material was removed by filtration using celite column, and the filtrate was concentrated. The residue was purified by silica column chromatography using hexane- $\mathrm{CH}_{2} \mathrm{Cl}_{2}(4: 1 \mathrm{v} / \mathrm{v})$ as eluent to give $\mathbf{1 a}$ as a white solid (218 mg, 80\%). Single crystals suitable for X-ray crystal structure analysis were obtained by recrystallization from $\mathrm{CH}_{2} \mathrm{Cl}_{2}-\mathrm{MeOH}$. 1a: $\mathrm{C}_{37} \mathrm{H}_{25} \mathrm{~N}_{3} \mathrm{~S}$; MW 543.69; mp 293-294 ${ }^{\circ} \mathrm{C} ;{ }^{1} \mathrm{H}$ NMR $(300 \mathrm{MHz}$, DMSO- $\left.d_{6}\right): \delta(\mathrm{ppm}) 8.24(\mathrm{~d}, J=7.6 \mathrm{~Hz}, 4 \mathrm{H}), 7.51-7.26(\mathrm{~m}, 18 \mathrm{H})$, $3.54(\mathrm{~s}, 3 \mathrm{H}) ;{ }^{13} \mathrm{C}$ NMR $\left(75 \mathrm{MHz}\right.$, THF- $\left.d_{8}\right): \delta(\mathrm{ppm}) 147.93,142.65$, 142.06, 128.92, 128.55, 124.72, 124.15, 124.07, 123.00, 122.55, 121.98, 114.51, 34.60; HRMS (MALDI-TOF ${ }^{+}$) $\mathrm{m} / \mathrm{z}$ calcd for $\mathrm{C}_{37} \mathrm{H}_{25} \mathrm{~N}_{3} \mathrm{~S}$ : 543.1769, found: $543.1764\left[\mathrm{M}^{+}\right]$; anal. calcd for $\mathrm{C}_{37} \mathrm{H}_{25} \mathrm{~N}_{3} \mathrm{~S}$ : C, 81.74; H, 4.64; N, 7.73. Found: C, 81.57; H, $4.72 ; \mathrm{N}, 7.68$.

3,7-Bis(10,11-dihydro-5H-dibenzo[b,f]azepin-5-yl)-10-methyl10H-phenothiazine (1b). A mixture of dibromophenothiazine 3 (74.5 mg, $0.201 \mathrm{mmol}$ ), 10,11-dihydro-5H-dibenzo[$[b, f]$ azepine (4b) (101 mg, $0.517 \mathrm{mmol}), \mathrm{Pd}_{2}(\mathrm{dba})_{3} \cdot \mathrm{CHCl}_{3} \quad(6.4 \mathrm{mg}$, $0.006 \mathrm{mmol})$, a toluene solution of $t \mathrm{Bu}_{3} \mathrm{P}(30 \mathrm{mM}, 0.04 \mathrm{~mL}$, $0.012 \mathrm{mmol}), \mathrm{NaO} t \mathrm{Bu}(61.2 \mathrm{mg}, 0.637 \mathrm{mmol})$, and toluene $(2 \mathrm{~mL})$ was stirred at $110{ }^{\circ} \mathrm{C}$ under a nitrogen atmosphere for $3 \mathrm{~h}$. After cooling to room temperature, the insoluble material was removed by filtration using a celite column, and the filtrate was concentrated. The residue was purified by alumina column chromatography using hexane- $\mathrm{CH}_{2} \mathrm{Cl}_{2}(6: 1 \mathrm{v} / \mathrm{v})$ as eluent to give $1 \mathbf{b}$ as a white solid (102 mg, 85\%). 1b: $\mathrm{C}_{41} \mathrm{H}_{33} \mathrm{~N}_{3} \mathrm{~S}$; MW 599.80; mp $271{ }^{\circ} \mathrm{C}$ (decomp.); ${ }^{1} \mathrm{H}$ NMR (300 MHz, DMSO- $d_{6}$ ): $\delta(\mathrm{ppm}) 7.33-7.24(\mathrm{~m}, 16 \mathrm{H}), 6.68(\mathrm{~d}, J=8.9 \mathrm{~Hz}, 2 \mathrm{H}), 6.27$ (dd, $J=$
8.9 and $2.6 \mathrm{~Hz}, 2 \mathrm{H}), 6.18(\mathrm{~d}, J=2.6 \mathrm{~Hz}, 2 \mathrm{H}), 3.10(\mathrm{~s}, 3 \mathrm{H}), 2.89$ (s, $8 \mathrm{H}) ;{ }^{13} \mathrm{C}$ NMR (75 MHz, THF- $d_{8}$ ): $\delta$ (ppm) 144.82, 143.76, 138.45, 138.14, 130.69, 129.97, 126.76, 126.69, 124.08, 113.45, 111.67, 111.53, 34.12, 30.75; HRMS (MALDI-TOF ${ }^{+}$) $\mathrm{m} / \mathrm{z}$ calcd for $\mathrm{C}_{41} \mathrm{H}_{33} \mathrm{~N}_{3} \mathrm{~S}$ : 599.2395, found: $599.2391\left[\mathrm{M}^{+}\right]$; anal calcd for $\mathrm{C}_{41} \mathrm{H}_{33} \mathrm{~N}_{3} \mathrm{~S}: \mathrm{C}, 82.10 ; \mathrm{H}, 5.55 ; \mathrm{N}$, 7.01. Found: C, 82.47; H, $5.77 ; \mathrm{N}, 6.77$.

3,7-Bis(5H-dibenzo[b,f]azepin-5-yl)-10-methyl-10H-phenothiazine (1c). A mixture of dibromophenothiazine 3 (186 mg, $0.501 \mathrm{mmol}$ ), iminostilbene (4c) (194 mg, $1.00 \mathrm{mmol}$ ), $\mathrm{Pd}_{2}(\mathrm{dba})_{3} \cdot \mathrm{CHCl}_{3}(15.4 \mathrm{mg}, 0.149 \mathrm{mmol})$, a toluene solution of $t \mathrm{Bu}_{3} \mathrm{P}(40 \mathrm{mM}, 0.75 \mathrm{~mL}, 0.03 \mathrm{mmol}$ ), $\mathrm{NaO} t \mathrm{Bu}(144 \mathrm{mg}$, $1.50 \mathrm{mmol})$, and toluene $(5 \mathrm{~mL})$ was stirred at $110{ }^{\circ} \mathrm{C}$ under a nitrogen atmosphere for $2 \mathrm{~h}$. After cooling to room temperature, the insoluble material was removed by filtration using celite column, and the filtrate was concentrated. The residue was purified by alumina column chromatography using hexane- $\mathrm{CH}_{2} \mathrm{Cl}_{2}(2: 1 \mathrm{v} / \mathrm{v})$ as eluent to give $1 \mathrm{c}$ as a white solid (219 mg, 73\%). Single crystals suitable for X-ray structure analysis were obtained by recrystallization from THFMeOH. 1c: $\mathrm{C}_{41} \mathrm{H}_{29} \mathrm{~N}_{3} \mathrm{~S}$; MW 595.76; mp $291{ }^{\circ} \mathrm{C}$ (decomp.); ${ }^{1} \mathrm{H}$ NMR (300 MHz, DMSO- $d_{6}$ ): $\delta$ (ppm) 7.57-7.41 (m, 16H), 6.87 $(\mathrm{s}, 4 \mathrm{H}), 6.52(\mathrm{~d}, J=8.8 \mathrm{~Hz}, 2 \mathrm{H}), 5.86(\mathrm{dd}, J=8.8$ and $2.8 \mathrm{~Hz}$, $2 \mathrm{H}), 5.75(\mathrm{~d}, J=2.8 \mathrm{~Hz}, 2 \mathrm{H}), 2.99(\mathrm{~s}, 3 \mathrm{H}) ;{ }^{13} \mathrm{C} \mathrm{NMR}(75 \mathrm{MHz}$, THF- $\left.d_{8}\right): \delta(\mathrm{ppm}) 144.43,143.61,138.36,136.76,130.52$, 130.33, 130.29, 129.45, 126.82, 123.59, 112.93, 110.65, 110.51, 34.01; HRMS (MALDI-TOF ${ }^{+}$m/z calcd for $\mathrm{C}_{41} \mathrm{H}_{29} \mathrm{~N}_{3} \mathrm{~S}$ : 595.2082, found: $595.2076\left[\mathrm{M}^{+}\right]$.

10-Methyl- $N, N, N^{\prime}, N^{\prime}$-tetraphenyl-10- $H$-phenothiazine-3,7diamine (1d). A mixture of dibromophenothiazine $3(188 \mathrm{mg}$, $0.507 \mathrm{mmol}$ ), diphenylamine (4d) (212 $\mathrm{mg}, 1.25 \mathrm{mmol})$, $\mathrm{Pd}_{2}(\mathrm{dba})_{3} \cdot \mathrm{CHCl}_{3}(21.0 \mathrm{mg}, 0.002 \mathrm{mmol})$, a toluene solution of $t \mathrm{Bu}_{3} \mathrm{P}(30 \mathrm{mM}, 0.14 \mathrm{~mL}, 0.004 \mathrm{mmol}), \mathrm{NaO} t \mathrm{Bu}(143 \mathrm{mg}$, $1.49 \mathrm{mmol})$, and toluene $(5 \mathrm{~mL})$ was stirred at $110{ }^{\circ} \mathrm{C}$ under a nitrogen atmosphere for $2 \mathrm{~h}$. After cooling to room temperature, the insoluble material was removed by filtration using celite column, and the filtrate was concentrated. The residue was purified by silica column chromatography using hexane$\mathrm{CH}_{2} \mathrm{Cl}_{2}(10: 1 \mathrm{v} / \mathrm{v})$ as eluent to give $1 \mathrm{~d}$ as a white solid (276 mg, $99 \%)$. Single crystals suitable for X-ray crystal structure analysis were obtained by recrystallization from $\mathrm{CH}_{2} \mathrm{Cl}_{2}-\mathrm{MeOH}$. 1d: $\mathrm{C}_{37} \mathrm{H}_{29} \mathrm{~N}_{3} \mathrm{~S}$; MW 547.72; mp 219-220 ${ }^{\circ} \mathrm{C} ;{ }^{1} \mathrm{H}$ NMR $(300 \mathrm{MHz}$, DMSO- $\left.d_{6}\right): \delta(\mathrm{ppm}) 7.26(\mathrm{t}, J=7.7 \mathrm{~Hz}, 8 \mathrm{H}), 7.00-6.93(\mathrm{~m}, 16 \mathrm{H})$, $6.80(\mathrm{~s}, 2 \mathrm{H}), 3.29(\mathrm{~s}, 3 \mathrm{H}) ;{ }^{13} \mathrm{C} \mathrm{NMR}\left(75 \mathrm{MHz}, \mathrm{THF}-d_{8}\right): \delta(\mathrm{ppm})$ 143.22 , 139.30, 130.71, 127.70, 123.84, 123.81, 122.76, 121.42, 118.07, 117.75, 113.31, 107.57, 33.14; HRMS (MALDI-TOF ${ }^{+}$) m/z calcd for $\mathrm{C}_{37} \mathrm{H}_{29} \mathrm{~N}_{3} \mathrm{~S}$ : 547.2082, found: 547.2077 [ $\mathrm{M}^{+}$]; anal. calcd for $\mathrm{C}_{37} \mathrm{H}_{29} \mathrm{~N}_{3} \mathrm{~S}: \mathrm{C}, 81.14 ; \mathrm{H}, 5.34 ; \mathrm{N}, 7.67$. Found: C, 80.88; $\mathrm{H}$, $5.38 ; \mathrm{N}, 7.52$.

10'-Methyl-10' $H$-10, $3^{\prime}: 7^{\prime}, \mathbf{1 0}^{\prime \prime}$-terphenothiazine (1e). A mixture of dibromophenothiazine $3(87.0 \mathrm{mg}, 0.234 \mathrm{mmol})$, phenothiazine (4e) (119 mg, $0.597 \mathrm{mmol}), \mathrm{Pd}_{2}(\mathrm{dba})_{3} \cdot \mathrm{CHCl}_{3}$ (2.4 mg, $0.002 \mathrm{mmol}$ ), a toluene solution of $t \mathrm{Bu}_{3} \mathrm{P}(30 \mathrm{mM}$, $0.16 \mathrm{~mL}, 0.005 \mathrm{mmol}), \mathrm{NaO} t \mathrm{Bu}(68.1 \mathrm{mg}, 0.709 \mathrm{mmol})$, and toluene $(2 \mathrm{~mL})$ was stirred at $110{ }^{\circ} \mathrm{C}$ under a nitrogen atmosphere for $2 \mathrm{~h}$. After cooling to room temperature, the insoluble material was removed by filtration using celite column, and the 
filtrate was concentrated. The residue was purified by silica column chromatography using hexane- $\mathrm{CH}_{2} \mathrm{Cl}_{2}(4: 1 \mathrm{v} / \mathrm{v})$ as eluent to give 1e as a white solid (161 mg, 82\%). Single crystals suitable for X-ray crystal structure analysis were obtained by recrystallization from toluene-hexane. 1e: $\mathrm{C}_{37} \mathrm{H}_{25} \mathrm{~N}_{3} \mathrm{~S}_{3}$; MW 607.81; mp $293{ }^{\circ} \mathrm{C}$ (decomp.); ${ }^{1} \mathrm{H}$ NMR (300 MHz, DMSO- $d_{6}$ ): $\delta(\mathrm{ppm}) 7.34-7.24(\mathrm{~m}, 6 \mathrm{H}), 7.05(\mathrm{dd}, J=7.5$ and $1.4 \mathrm{~Hz}, 4 \mathrm{H}), 6.95$ $(\mathrm{td}, J=7.5$ and $1.4 \mathrm{~Hz}, 4 \mathrm{H}), 6.85(\mathrm{td}, J=7.5$ and $1.4 \mathrm{~Hz}, 4 \mathrm{H}), 6.25$ (dd, $J=7.5$ and $1.4 \mathrm{~Hz}, 4 \mathrm{H}), 3.48(\mathrm{~s}, 3 \mathrm{H}) ;{ }^{13} \mathrm{C}$ NMR $(75 \mathrm{MHz}$, THF- $\left.d_{8}\right): \delta(\mathrm{ppm}) 143.59,142.49,133.87,128.41,127.44,124.79$, $124.43,123.35,120.33,118.22,114.08,113.95$, 33.13; HRMS (MALDI-TOF ${ }^{+}$) $m / z$ calcd for $\mathrm{C}_{37} \mathrm{H}_{25} \mathrm{~N}_{3} \mathrm{~S}_{3}$ : 607.1211, found: $607.1206\left[\mathrm{M}^{+}\right]$; anal. calcd for $\mathrm{C}_{37} \mathrm{H}_{25} \mathrm{~N}_{3} \mathrm{~S}_{3}: \mathrm{C}, 73.12 ; \mathrm{H}, 4.15 ; \mathrm{N}$, 6.91. Found: C, 73.28; H, 4.44; N, 6.81.

10-Methyl-3,7-bis(10H-phenoxazin-10-yl)-10H-phenothiazine (1f). A mixture of dibromophenothiazine $3(74.3 \mathrm{mg}, 0.200 \mathrm{mmol})$, phenoxazine (4f) $(77.7 \mathrm{mg}, 0.424 \mathrm{mmol}), \quad \mathrm{Pd}_{2}(\mathrm{dba})_{3} \cdot \mathrm{CHCl}_{3}$ $(4.1 \mathrm{mg}, 4.0 \mathrm{mmol})$, a toluene solution of $t \mathrm{Bu}_{3} \mathrm{P}(30 \mathrm{mM}, 0.27 \mathrm{~mL}$, $0.008 \mathrm{mmol}), \mathrm{NaO} t \mathrm{Bu}(61.3 \mathrm{mg}, 0.638 \mathrm{mmol})$, and toluene $(2 \mathrm{~mL})$ was stirred at $110{ }^{\circ} \mathrm{C}$ under a nitrogen atmosphere for $5 \mathrm{~h}$. After cooling to room temperature, the insoluble material was removed by filtration using celite column, and the filtrate was concentrated. The residue was purified by silica column chromatography using hexane- $\mathrm{CH}_{2} \mathrm{Cl}_{2}(5: 1)$ as eluent to give $\mathbf{1 f}$ as a white solid (103 mg, 90\%). Single crystals suitable for X-ray structure analysis were obtained by recrystallization from THF-water. 1f: $\mathrm{C}_{37} \mathrm{H}_{25} \mathrm{~N}_{3} \mathrm{O}_{2} \mathrm{~S}$; MW 575.69; mp > $300{ }^{\circ} \mathrm{C} ;{ }^{1} \mathrm{H}$ NMR $(300 \mathrm{MHz}$, DMSO- $\left.d_{6}\right): \delta(\mathrm{ppm})$ 7.31-7.23 (m, 6H), 6.74-6.65 (m, 12H), 5.96-5.93 (m, 4H), $3.46(\mathrm{~s}, 3 \mathrm{H}) ;{ }^{13} \mathrm{C}$ NMR (75 MHz, THF- $\left.d_{8}\right)$ : $\delta(\mathrm{ppm}) 145.57,143.96,134.38,133.89,129.94,128.86$, 125.58, 123.07, 121.06, 116.26, 115.03, 113.29, 34.99; HRMS $\left(\right.$ MALDI-TOF $^{+}$) $\mathrm{m} / \mathrm{z}$ calcd for $\mathrm{C}_{37} \mathrm{H}_{25} \mathrm{~N}_{3} \mathrm{O}_{2} \mathrm{~S}$ : 575.1667, found: $575.1663\left[\mathrm{M}^{+}\right]$.

Radical cation hexafluoroantimonate salt $\mathbf{1 a}^{\cdot+} \cdot \mathrm{SbF}_{6}{ }^{-}$. To a solution of compound $1 \mathrm{a}(30.2 \mathrm{mg}, 0.056 \mathrm{mmol})$ in $\mathrm{CH}_{2} \mathrm{Cl}_{2}$ $(4 \mathrm{~mL})$ was added $\mathbf{T B P A}^{++} \cdot \mathbf{S b F}_{\mathbf{6}}{ }^{-}(40.5 \mathrm{mg}, 0.056 \mathrm{mmol})$ at room temperature, and the mixture was stirred at room temperature for $1 \mathrm{~h}$. The mixture was concentrated under reduced pressure, then $\mathrm{Et}_{2} \mathrm{O}$ was added to the residue. The precipitate was collected by filtration and dried under reduced pressure to give

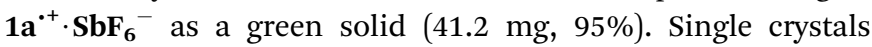
suitable for $\mathrm{X}$-ray crystal analysis were obtained by the following method: $\mathbf{1 a}^{\cdot+} \cdot \mathbf{S b F}_{\mathbf{6}}{ }^{-}$was dissolved in a least amount of $\mathrm{CH}_{3} \mathbf{C N}$ and the solution was placed in a small open bottle. The bottle is placed in a larger bottle containing benzene, and the larger bottle was capped. The capped bottle was placed in a refrigerator overnight, and then the crystals were precipitated by slowly mixing the benzene vapor into the $\mathrm{CH}_{3} \mathrm{CN}$ layer. $\mathbf{1 a}^{\cdot+} \cdot \mathbf{S b F}_{\mathbf{6}}{ }^{-}$: $\mathrm{C}_{37} \mathrm{H}_{25} \mathrm{~N}_{3} \mathrm{~S} \cdot \mathrm{SbF}_{6}$; MW 779.44; green solid; $\mathrm{mp}>300{ }^{\circ} \mathrm{C}$; EPR (powder) $g=2.0049 ;$ HRMS (MALDI-TOF ${ }^{+}$) $\mathrm{m} / \mathrm{z}$ calcd for $\mathrm{C}_{37} \mathrm{H}_{25} \mathrm{~N}_{3} \mathrm{~S}^{+}$: 543.1769, found: 543.1765; HRMS (MALDI-TOF ${ }^{-}$) $\mathrm{m} / z$ calcd for $\mathrm{SbF}_{6}{ }^{-}: 234.8942$, found: 234.8947; anal. calcd for $\left(\mathrm{C}_{37} \mathrm{H}_{25} \mathrm{~N}_{3} \mathrm{~S} \cdot \mathrm{SbF}_{6}\right)_{3} \cdot \mathrm{C}_{6} \mathrm{H}_{6} \cdot\left(\mathrm{CH}_{3} \mathrm{CN}\right)_{2}: \mathrm{C}, 58.17 ; \mathrm{H}, 3.51 ; \mathrm{N}, 6.17$. Found: C, 58.21; H, 3.74; N, 6.42.

Radical cation hexafluoroantimonate salt $\mathbf{1 b}^{\cdot+} \cdot \mathbf{S b F}_{6}{ }^{-}$. To a solution of compound $\mathbf{1 b}(20.0 \mathrm{mg}, 0.033 \mathrm{mmol})$ in $\mathrm{CH}_{2} \mathrm{Cl}_{2}$ (2 mL) was added $\mathbf{T B P A}^{\cdot+} \cdot \mathbf{S b F}_{\mathbf{6}}{ }^{-}(24.1 \mathrm{mg}, 0.034 \mathrm{mmol})$ at room temperature, and the mixture was stirred at room temperature for $1 \mathrm{~h}$. The mixture was concentrated under reduced pressure, then $\mathrm{Et}_{2} \mathrm{O}$ was added to the residue. The precipitate was collected by filtration and dried under reduced pressure to give $\mathbf{1 b}^{{ }^{+}} \cdot \mathbf{S b F}_{\mathbf{6}}{ }^{-}$as a yellow solid $(24.5 \mathrm{mg}, 88 \%)$. Single crystals for $\mathrm{X}$-ray structure analysis were obtained by recrystallization from chlorobenzene-pentane. $\quad \mathbf{1 b}^{\cdot+} \cdot \mathbf{S b F}_{6}{ }^{-}: \quad \mathrm{C}_{41} \mathrm{H}_{33} \mathrm{~F}_{30} \mathrm{~N}_{15} \mathrm{~S}_{5} \cdot \mathrm{SbF}_{6}$; MW 835.55; yellow solid; mp $230{ }^{\circ} \mathrm{C}$ (decomp.); EPR (powder) $g$ $=2.0041$; HRMS (MALDI-TOF ${ }^{+}$) $m / z$ calcd for $\mathrm{C}_{41} \mathrm{H}_{33} \mathrm{~N}_{3} \mathrm{~S}^{+}$: 599.2395, found: 599.2389; HRMS (MALDI-TOF ${ }^{-}$) $\mathrm{m} / z$ calcd for $\mathrm{SbF}_{6}{ }^{-}$: 234.8942, found: 234.8947; anal. calcd for $\left(\mathrm{C}_{41} \mathrm{H}_{33} \mathrm{~N}_{3}{ }^{-}\right.$ $\left.\mathrm{S} \cdot \mathrm{SbF}_{6}\right)_{5} \cdot\left(\mathrm{C}_{6} \mathrm{H}_{5} \mathrm{Cl}\right)_{2}: \mathrm{C}, 59.20 ; \mathrm{H}, 4.01 ; \mathrm{N}, 4.77$. Found: C, 58.98; $\mathrm{H}, 4.12$; N, 4.53.

Radical cation tetrabromogallate salt $1 \mathrm{c}^{\cdot+} \cdot \mathrm{GaBr}_{4}{ }^{-}$. To a solution of compound $1 \mathrm{c}(20.5 \mathrm{mg}, 0.034 \mathrm{mmol})$ in $\mathrm{CH}_{2} \mathrm{Cl}_{2}$ $(2 \mathrm{~mL})$ was added $\mathbf{T H}^{{ }^{+}} \cdot \mathbf{G a B r}_{\mathbf{4}}{ }^{-}(21.4 \mathrm{mg}, 0.035 \mathrm{mmol})$ at room temperature, and the mixture was stirred at room temperature for $1 \mathrm{~h}$. The mixture was concentrated under reduced pressure, then $\mathrm{Et}_{2} \mathrm{O}$ was added to the residue. The precipitate was collected by filtration and dried under reduced pressure to give $\mathbf{1 c}^{\cdot+} \cdot \mathbf{G a B r}_{4}{ }^{-}$as a green solid $(26.0 \mathrm{mg}, 77 \%)$. Analytically pure sample was obtained by recrystallization from $\mathrm{CH}_{2} \mathrm{Cl}_{2}-\mathrm{Et}_{2} \mathrm{O}$. Single crystals for X-ray crystal structure analysis were obtained by recrystallization from chlorobenzene-cyclohexane. ${ }_{1 c^{*+}} \cdot \mathrm{GaBr}_{4}{ }^{-}: \mathrm{C}_{41} \mathrm{H}_{29} \mathrm{~N}_{3} \mathrm{~S} \cdot \mathrm{GaBr}_{4} ; \mathrm{MW}$ 985.10; green solid; mp > $300{ }^{\circ} \mathrm{C}$; EPR (powder) $g=2.0043$; anal. calcd for $\left(\mathrm{C}_{41} \mathrm{H}_{29} \mathrm{~N}_{3}\right.$ $\left.\mathrm{S} \cdot \mathrm{GaBr}_{4}\right)_{2} \cdot \mathrm{CH}_{2} \mathrm{Cl}_{2}: \mathrm{C}, 48.51 ; \mathrm{H}, 2.94 ; \mathrm{N}, 4.09$. Found: $\mathrm{C}, 48.72 ; \mathrm{H}$, 3.06; N, 4.16 .

Radical cation hexafluoroantimonate salt $\mathbf{1 d}^{\cdot+} \cdot \mathrm{SbF}_{6}{ }^{-}$. To a solution of compound $1 \mathbf{d}(20.1 \mathrm{mg}, 0.037 \mathrm{mmol})$ in $\mathrm{CH}_{2} \mathrm{Cl}_{2}$ (4 mL) was added $\mathbf{T B P A}^{{ }^{+}} \cdot \mathbf{S b F}_{\mathbf{6}}{ }^{-}(25.7 \mathrm{mg}, 0.036 \mathrm{mmol})$ at room temperature, and the mixture was stirred at room temperature for $1 \mathrm{~h}$. The mixture was concentrated under reduced pressure, then $\mathrm{Et}_{2} \mathrm{O}$ was added to the residue. The precipitate was collected by filtration and dried under reduced pressure to give $\mathbf{1 d}^{\cdot+} \cdot \mathbf{S b F}_{\mathbf{6}}{ }^{-}$as a brown solid $(20.3 \mathrm{mg}, 72 \%)$. Single crystals for $\mathrm{X}$-ray crystal structure analysis were obtained by recrystallization from $\mathrm{CH}_{2} \mathrm{Cl}_{2}$-hexane. $\mathbf{1 d}^{\cdot+} \cdot \mathbf{S b F}_{\mathbf{6}}{ }^{-}: \mathrm{C}_{37} \mathrm{H}_{29} \mathrm{~N}_{3} \mathrm{~S} \cdot \mathrm{SbF}_{6} ; \mathrm{MW}$ 783.47; brown solid; mp $173{ }^{\circ} \mathrm{C}$ (decomp.); EPR (powder) $g=$ 2.0039; HRMS (MALDI-TOF ${ }^{+}$) $\mathrm{m} / z$ calcd for $\mathrm{C}_{37} \mathrm{H}_{29} \mathrm{~N}_{3} \mathrm{~S}^{+}$: 547.2082, found: 547.2076; HRMS (MALDI-TOF ${ }^{-}$) $\mathrm{m} / z$ calcd for $\mathrm{SbF}_{6}{ }^{-}: 234.8942$, found: 234.8947 .

Radical cation hexafluoroantimonate salt $1 \mathrm{e}^{\cdot+} \cdot \mathrm{SbF}_{\mathbf{6}}{ }^{-}$. To a solution of compound $1 \mathrm{e}(20.3 \mathrm{mg}, 0.033 \mathrm{mmol})$ in $\mathrm{CH}_{2} \mathrm{Cl}_{2}$ $(2 \mathrm{~mL})$ was added $\mathbf{T B P A}^{\cdot+} \cdot \mathbf{S b F}_{\mathbf{6}}{ }^{-}(24.1 \mathrm{mg}, 33.6 \mathrm{mmol})$ at room temperature, and the mixture was stirred at room temperature for $1 \mathrm{~h}$. The mixture was concentrated under reduced pressure, then $\mathrm{Et}_{2} \mathrm{O}$ was added to the residue. The precipitate was collected by filtration and dried under reduced pressure to give $\mathbf{1 e}^{\cdot+} \cdot \mathbf{S b F}_{\mathbf{6}}{ }^{-}$as a black solid (26.3 mg, 93\%). Single crystals for Xray crystal structure analysis were obtained by recrystallization from $\mathrm{CH}_{2} \mathrm{Cl}_{2}$-toluene. $\quad \mathbf{1 e}^{\cdot+} \cdot \mathbf{S b F}_{6}{ }^{-}: \mathrm{C}_{37} \mathrm{H}_{25} \mathrm{~N}_{3} \mathrm{~S}_{3} \cdot \mathrm{SbF}_{6} ; \quad \mathrm{MW}$ 843.56; black solid; $\mathrm{mp}>300{ }^{\circ} \mathrm{C}$; EPR (powder) $g=2.0041$; HRMS (MALDI-TOF ${ }^{+}$) $\mathrm{m} / z$ calcd for $\mathrm{C}_{37} \mathrm{H}_{25} \mathrm{~N}_{3} \mathrm{~S}_{3}$ : 607.1211, found: 607.1206; HRMS (MALDI-TOF ${ }^{-}$) $\mathrm{m} / z$ calcd for $\mathrm{SbF}_{6}{ }^{-}$: 234.8942, found: 234.8947; anal. calcd for $\mathrm{C}_{37} \mathrm{H}_{25} \mathrm{~N}_{3} \mathrm{~S}_{3} \cdot \mathrm{SbF}_{6}: \mathrm{C}$, 52.68; H, 2.99; N, 4.98. Found: C, 52.50; H, 3.42; N, 4.78. 
Radical cation tetrabromogallate salt $\mathbf{1 f}^{\cdot+} \cdot \mathrm{GaBr}_{4}{ }^{-}$. To a solution of compound $\mathbf{1 f}(20.3 \mathrm{mg}, 35.3 \mathrm{mmol})$ in $\mathrm{CH}_{2} \mathrm{Cl}_{2}$ (2 mL) was added $\mathbf{T H}^{\cdot+} \cdot \mathbf{G a B r}_{\mathbf{4}}{ }^{-}(21.4 \mathrm{mg}, 35.3 \mathrm{mmol})$ at room temperature, and the mixture was stirred at room temperature for $1 \mathrm{~h}$. The mixture was concentrated under reduced pressure, then $\mathrm{Et}_{2} \mathrm{O}$ was added to the mixture. The precipitate was collected by filtration and dried under reduced pressure (30.6 mg, 90\%). Single crystals for X-ray crystal structure analysis were obtained by recrystallization from $\mathrm{CH}_{2} \mathrm{Cl}_{2}$-cyclohexane. 1f $^{+} \cdot \mathrm{GaBr}_{4}{ }^{-}: \mathrm{C}_{37} \mathrm{H}_{25} \mathrm{~N}_{3} \mathrm{O}_{2} \mathrm{~S} \cdot \mathrm{GaBr}_{4}$; MW 965.03; purple solid; mp $>300{ }^{\circ} \mathrm{C}$; EPR (powder) $g=2.0042$; HRMS (MALDI$\left.\mathrm{TOF}^{+}\right)^{2} \mathrm{~m} / z \quad 575.1661 \quad\left[\mathrm{C}_{37} \mathrm{H}_{25} \mathrm{~N}_{3} \mathrm{O}_{2} \mathrm{~S}^{+}\right], \quad\left(\mathrm{MALDI}^{-T O F}{ }^{-}\right) \mathrm{m} / \mathrm{z}$ $384.5995\left[\mathrm{GaBr}_{4}{ }^{-}\right.$]; anal. calcd for $\mathrm{C}_{37} \mathrm{H}_{25} \mathrm{~N}_{3} \mathrm{O}_{2} \mathrm{~S} \cdot \mathrm{GaBr}_{4}$ : C, 46.05; H, 2.61; N, 4.35. Found: C, 46.02; H, 2.74; N, 4.54.

\section{Theoretical calculations}

All calculations were carried out on the basis of DFT with the (U) B3LYP exchange-correlation functional and using Gaussian 09 program packages. ${ }^{15}$ The basis set used was $6-31 G^{* *}$ for all atoms. The criterion for the SCF convergence was $10^{-9}$. Molecular orbitals for $\mathbf{1 a}-\mathbf{e}$ and $\mathbf{1 a}-\mathbf{e}^{\cdot+}$ were calculated by using the molecular geometries obtained from the optimized structures. The transition energies of $\mathbf{1 a}-\mathbf{e}^{\cdot+}$ were estimated by TDDFT calculation (UB3LYP/6-31G**).

\section{Conflicts of interest}

The authors declare no conflict of interest.

\section{Acknowledgements}

This work was partially supported by Grant-in-Aid for Scientific Research on Innovative Areas " $\pi$-System Figuration: Control of Electron and Structural Dynamism for Innovative Functions (2601)” (JSPS KAKENHI Grant Number JP26102005 for S. S.), "Stimuli-responsive Chemical Species for the Creation of Functional Molecules (2468)" (JSPS KAKENHI Grant Number JP15H00956 for K. O.), Grant-in-Aid for Scientific Research (JSPS KAKENHI Grant Number JP26288041 for K.O. and JP17K05783 for S. S.), and Iketani science and technology foundation (for S. S.). The authors thank Prof. Dr Hiroyuki Miyake and Prof. Dr Satoshi Shinoda of Graduate School of Science, Osaka City University for measuring UV-vis-NIR spectra.

\section{Notes and references}

1 (a) Y. Shirota, J. Mater. Chem., 2000, 10, 1; (b) M. Thelakkat, Macromol. Mater. Eng., 2002, 287, 442; (c) Y. Shirota and H. Kageyama, Chem. Rev., 2007, 107, 953; (d) Y. Tao, C. Yang and J. Qin, Chem. Soc. Rev., 2011, 40, 2943.

2 (a) P. Bujak, I. Kulszewicz-Bajer, M. Zagorska, V. Maurel, I. Wielgus and A. Pron, Chem. Soc. Rev., 2013, 42, 8895; (b) S. C. Blackstock and T. D. Selby, in Magnetic Properties of Organic Materials, ed. P. M. Lahti, Marcel Dekker, New York, 1999, ch. 9, p. 165; (c) R. J. Bushby, in Magnetic Properties of Organic Materials, ed. P. M. Lahti, Marcel
Dekker, New York, 1999, ch. 10, p. 179; (d) S. Suzuki, K. Yoshida, M. Kozaki and K. Okada, Angew. Chem., Int. Ed., 2013, 52, 2499; (e) K. Yoshida, S. Suzuki, M. Kozaki and K. Okada, Chem. Lett., 2016, 45, 203.

3 (a) L.-L. Li and E. W.-G. Diau, Chem. Soc. Rev., 2013, 42, 291;

(b) M. Liang and J. Chen, Chem. Soc. Rev., 2013, 42, 3453; (c) Y. Hua, S. Chang, D. Huang, X. Zhou, X. Zhu, J. Zhao, T. Chen, W.-Y. Wong and W.-K. Wong, Chem. Mater., 2013, 25, 2146; (d) G. Kim, H. R. Yeom, S. Cho, J. H. Seo, J. Y. Kim and C. Yang, Macromolecules, 2012, 45, 1847; (e) G. Sang, Y. Zou and Y. Li, J. Phys. Chem. C, 2008, 112, 12058. 4 (a) Y. Karimata, S. Suzuki, M. Kozaki, K. Kimoto, K. Nozaki, H. Matsushita, N. Ikeda, K. Akiyama, D. Kosumi, H. Hashimoto and K. Okada, J. Phys. Chem. A, 2014, 118, 11262; (b) R. Sugimura, S. Suzuki, M. Kozaki, K. Keyaki, K. Nozaki, H. Matsushita, N. Ikeda and K. Okada, Res. Chem. Intermed., 2013, 39, 185; (c) S. Suzuki, M. Kozaki, K. Nozaki and K. Okada, J. Photochem. Photobiol., C, 2011, 12, 269.

5 (a) H. Tanaka, K. Shizu, H. Nakanotani and C. Adachi, J. Phys. Chem. C, 2014, 118, 15985; (b) Z. Xie, C. Chen, S. Xu, J. Li, Y. Zhang, S. Liu, J. Xu and Z. Chi, Angew. Chem., Int. Ed., 2015, 54, 7181; (c) M. Okazaki, Y. Takeda, P. Data, P. Pander, H. Higginbotham, A. P. Monkman and S. Minakata, Chem. Sci., 2017, 8, 2677.

6 (a) T. J. LePage and R. Breslow, J. Am. Chem. Soc., 1987, 109, 6412; (b) S. V. Rosokha and J. K. Kochi, J. Am. Chem. Soc., 2007, 129, 3683.

7 For 3-dimethylamino-substituted phenothiazines for instance: J. Bae, L. E. McNamara, M. A. Nael, F. Mahdi, R. J. Doerksen, G. L. Bidwell III, N. I. Hammer and S. Jo, Chem. Commun., 2015, 51, 12787; For 3alkyloxyphenothiazines: See, ref. $3 c$; For 3arylphenothiazines: L. Yao, Y. Pan, X. Tang, Q. Bai, F. Shen, F. Li, P. Lu, B. Yang and Y. Ma, J. Phys. Chem. C, 2015, 119, 17800.

8 I. S. Perețeanu and T. J. J. Müller, Org. Biomol. Chem., 2013, 11, 5127.

9 T. Okamoto, M. Kuratsu, M. Kozaki, K. Hirotsu, A. Ichimura, T. Matsushita and K. Okada, Org. Lett., 2004, 6, 3493.

10 H.-H. Lin and C.-C. Chang, Dyes Pigm., 2009, 83, 230-236.

11 CCDC 1572168 (1a), $1572169\left(\mathbf{1 a}^{\cdot+} \cdot \mathbf{S b F}_{\mathbf{6}}{ }^{-}\right), 1572170\left(\mathbf{1 b}^{\prime}\right)$, $1572171\left(\mathbf{1 b}^{{ }^{++}} \cdot \mathbf{S b F}_{\mathbf{6}}{ }^{-}\right), 1572172(\mathbf{1 c}), 1572173\left(\mathbf{1 c}^{{ }^{++}} \cdot \mathbf{G a B r}_{\mathbf{4}}{ }^{-}\right)$, 1572175 (1d), $1572186\left(\mathbf{1 d}^{\cdot+} \cdot \mathbf{S b F}_{\mathbf{6}}{ }^{-}\right), 1572187(\mathbf{1 e}), 1572188$ $\left(\mathbf{1 e}^{\cdot+} \cdot \mathbf{S b F}_{\mathbf{6}}{ }^{-}\right), 1572500$ (1f), and $1572190\left(\mathbf{1 f}^{\cdot+} \cdot \mathbf{G a B r}_{\mathbf{4}}{ }^{-}\right)$ contain the supplementary crystallographic data for this paper. $\dagger$

12 M. Kuratsu, S. Suzuki, M. Kozaki, D. Shiomi, K. Sato, T. Takui and K. Okada, Inorg. Chem., 2007, 46, 10153.

13 The Cyclic voltammograms of 1a-e showed second oneelectron oxidation process, suggesting the strong donating abilities of the $\mathrm{Ar}_{2} \mathrm{~N}$-substituents. The detailed investigations for molecular structures and electronic properties of the two-electron oxidized species are underway.

14 Neutral phenoxazine has a more planar structure because of the shorter $\mathrm{C}-\mathrm{O}$ bond length $(\sim 1.41 \AA$, Fig. $\mathrm{S} 2 \dagger)$ compared to the $\mathrm{C}-\mathrm{S}$ bond length $(\sim 1.76 \AA)$ in neutral phenothiazine. 
15 M. J. Frisch, G. W. Trucks, H. B. Schlegel, G. E. Scuseria, M. A. Robb, J. R. Cheeseman, G. Scalmani, V. Barone, B. Mennucci, G. A. Petersson, H. Nakatsuji, M. Caricato, X. Li, H. P. Hratchian, A. F. Izmaylov, J. Bloino, G. Zheng, J. L. Sonnenberg, M. Hada, M. Ehara, K. Toyota, R. Fukuda, J. Hasegawa, M. Ishida, T. Nakajima, Y. Honda, O. Kitao, H. Nakai, T. Vreven, J. A. Montgomery Jr, J. E. Peralta, F. Ogliaro, M. Bearpark, J. J. Heyd, E. Brothers, K. N. Kudin, V. N. Staroverov, R. Kobayashi, J. Normand, K. Raghavachari, A. Rendell, J. C. Burant, S. S. Iyengar, J. Tomasi, M. Cossi, N. Rega, J. M. Millam, M. Klene, J. E. Knox, J. B. Cross, V. Bakken, C. Adamo,
J. Jaramillo, R. Gomperts, R. E. Stratmann, O. Yazyev, A. J. Austin, R. Cammi, C. Pomelli, J. W. Ochterski, R. L. Martin, K. Morokuma, V. G. Zakrzewski, G. A. Voth, P. Salvador, J. J. Dannenberg, S. Dapprich, A. D. Daniels, Ö. Farkas, J. B. Foresman, J. V. Ortiz, J. Cioslowski and D. J. Fox, Gaussian 09, Revision A.02, Gaussian, Inc., Wallingford CT, 2009.

16 The geometries of $1 \mathbf{1}-\mathbf{e}$ and their radical cations were optimized using Gaussian 09 with density functional theory at the (U)B3LYP/6-31G* level of theory.

17 S. Suzuki and K. Okada, in Organic Redox Systems, ed. T. Nishinaga, John Wiley \& Sons, New Jersey, 2016, ch. 8, p. 269. 